\title{
Spatial variability in digenean metacercariae infection of 0-group common sole Solea solea among nurseries along the French Atlantic coast
}

\author{
Eric Dominique Henri Durieux ${ }^{1, *}$, Marie-Laure Bégout ${ }^{1}{ }$ Pierre Sasal $^{2}$ \\ ${ }^{1}$ Centre de Recherche sur les Ecosystèmes Littoraux Anthropisés, CRELA UMR 6217 CNRS-IFREMER-Université de La Rochelle, \\ Place du Séminaire, BP5, 17137 L'Houmeau, France \\ ${ }^{2}$ Laboratoire de Biologie et d'Ecologie Tropicale et Méditerranéenne, UMR 5244 CNRS-EPHE-UPVD, \\ Université de Perpignan Via Domitia, 52 Avenue Paul Alduy, 66860 Perpignan, France
}

\begin{abstract}
We sampled 0-group sole juveniles $(\mathrm{N}=174)$ in September and October 2003 in 9 major nurseries located along the French Atlantic coast (English Channel and Bay of Biscay). 0-group sole were infected with 3 genera of digenean metacercariae, Timoniella spp. (Acanthostomidae), Prosorhynchus crucibulum and Prosorhynchus sp. A (Bucephalidae), Podocotyle sp. (Opecoelidae), and an unidentified species of Digenea. Parasite infection levels in the English Channel nurseries were lower, and the community composition was different from Bay of Biscay nurseries. We hypothesize that the difference between geographic areas was due to differences in first intermediate host communities and, to a lesser extent, because of lower temperatures in the English Channel compared to the Bay of Biscay. For the Bay of Biscay nurseries, mean total parasite abundance was strongly negatively correlated with mean annual river flow. This relationship may be the result of the more upstream location of 0-group sole nurseries in estuaries so that fish were further from local points of parasite transmission than those in embayed nurseries. Digenean metacercariae load may be influenced by 3 major local factors, i.e. abundance and proximity of the first intermediate hosts and cercariae dispersal capacities.
\end{abstract}

KEY WORDS: Flatfish · Juveniles $\cdot$ Parasitism $\cdot$ Trematodes $\cdot$ Habitat quality $\cdot$ River flow Resale or republication not permitted without written consent of the publisher

\section{INTRODUCTION}

Coastal areas such as estuaries and shallow water bays serve as nurseries for many juveniles of commercially important marine fishes, especially flatfish (Gibson 1994, Beck et al. 2001). In these essential habitats, highly variable environmental conditions influence growth and survival of juveniles and hence recruitment into the adult population (Gibson 1994). Flatfish juveniles are relatively sedentary in nursery grounds and are especially affected by local conditions (Able et al. 1999). Habitat quality depends on a number of interdependent environmental and anthropogenic factors, and may influence the fitness of the species (Gibson 1994). Numerous factors have been taken into account to estimate flatfish nursery quality (Beck et al.
2001, Yamashita et al. 2001), but few papers dealt with the potential effects of parasitism.

Parasites can affect the physiology and population dynamics of their hosts (growth, condition, survival, fecundity, behavior), and thus their fitness (Combes 2001). They are a natural part of all ecosystems and can be considered as dominating regulators in food web links (Lafferty et al. 2006), giving parasitism a well recognized place as a factor that may impact coastal organisms (Thomas et al. 1997). In nursery grounds, 0group flatfish juveniles are frequently infected by digenean metacercariae (Trematoda), for which they serve as second intermediate host. Common sole Solea solea (Linnaeus, 1758) 0-group juveniles from the Pertuis Breton nursery ground on the French Atlantic coast are known to be infected by digenean metacer- 
cariae, including Prosorhynchus spp. (Bucephalidae) (Laffargue et al. 2004, Durieux et al. 2007). Durieux et al. (2007) suggested that heavy infections levels as well as low nutritional status of these fish could lower winter survival. Parasitism, therefore, is a factor that could potentially affect habitat quality of flatfish, and of sole in particular.

In the northeastern Atlantic region, sole has a constantly high commercial value and relatively high landings. Most sole stocks are reported to be overexploited (ICES 2005). Different nurseries contribute to recruitment within each single adult stock (Rijnsdorp et al. 1992, Le Pape et al. 2003a). Evaluation of habitat quality for juveniles in different nurseries is thus essential for stock management (Beck et al. 2001). For the Bay of Biscay stock, Le Pape et al. (2003a,b) highlighted the difference among sole nurseries in terms of both quantity and quality, based on growth performances of juveniles. Spatial variation in parasitism is commonly observed in host populations, and therefore may add an additional differential impact that varies among sites (Thomas et al. 2005).

In order to take parasitism into account in considerations of habitat quality of sole juveniles, our goal was to evaluate spatial variability of infection by digenean metacercariae of 0-group sole among different nurseries for 2 geographic stocks. Accordingly, we analysed 0-group sole from 9 nursery grounds along the French coast located along the English Channel and the Bay of Biscay, areas that correspond to 2 distinct sole stocks (ICES division VIId,e and VIIIa,b, respectively). We compared parasitic infection between and within the 2 distinct stocks. As nurseries sampling occurred in both embayments and estuaries, we tested the influence of river flow on the infection levels (by digenean metacercariae) in 0-group sole.

\section{MATERIALS AND METHODS}

Fish sampling and parasite collection. We sampled 0-group sole in September and October 2003 from 9 sites along the French Atlantic coast (English Channel and Bay of Biscay) (Fig. 1). We used a beam trawl $(2.9 \mathrm{~m}$ wide and $0.5 \mathrm{~m}$ high, mounted with a $20 \mathrm{~mm}$ stretched mesh net in the codend) at maximum depths between 5 and $20 \mathrm{~m}$, towed at 2.5 knots for $20 \mathrm{~min}$ as part of a IFREMER juvenile sole survey. Fish were immediately frozen and individually stored at $-20^{\circ} \mathrm{C}$. A total sample of 174 fish were individually weighed (to $0.01 \mathrm{~g}$, wet mass $\mathrm{M}_{\mathrm{W}}$ ) and measured (to $1 \mathrm{~mm}$, standard length SL) (Table 1). The sole were thawed and completely dissected (including all organs) under a binocular microscope to check for digenean metacercariae parasites. These were mechanically excysted, identi-

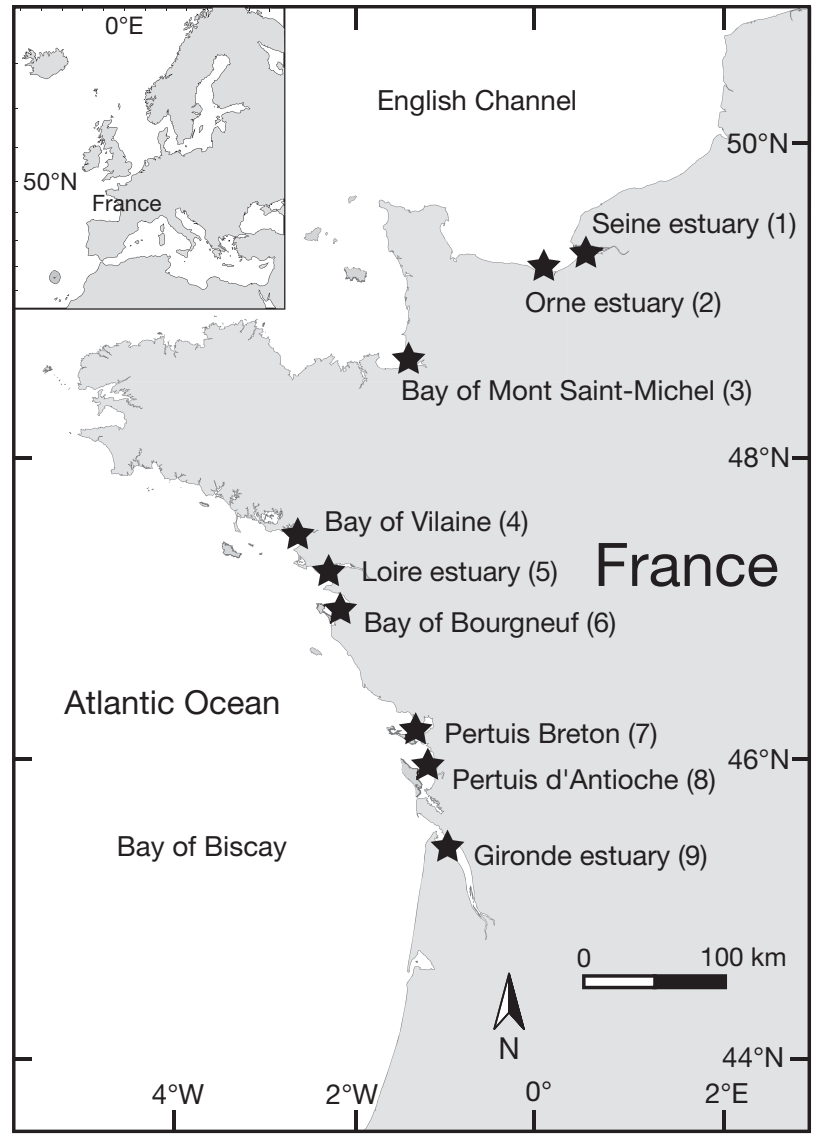

Fig. 1. Locations of the 9 nurseries sampled along the French Atlantic coasts of the English Channel (Sites 1 to 3) and the Bay of Biscay (Sites 4 to 9)

fied to the lowest taxonomical level possible on the basis of morphological features visible under a compound light microscope, and finally counted.

Data analysis. The parasitological indices of prevalence (percentage of fish infected), mean abundance (mean number of parasites per fish) and intensity (mean number of parasites per infected fish) were calculated for each sample according to Bush et al. (1997).

Values are given as mean \pm SE for parasite mean abundance, mean (maximum) for parasite intensity and mean \pm SD for SL. Fulton's condition index was calculated as $\mathrm{K}=\left(\mathrm{M}_{\mathrm{W}} \times 100\right) \mathrm{SL}^{-3}$, with $\mathrm{M}_{\mathrm{W}}$ in $\mathrm{g}$ and $\mathrm{SL}$ in $\mathrm{cm}$. Mean 2003 annual river flow data were obtained from the national hydrological databank of the French Ministry of the Environment (www.hydro.eaufrance.fr) (Table 1).

Differences in parasite abundance between areas were analysed using the non-parametric KruskalWallis test (KW), because individuals in macroparasite populations tend to be aggregated, leading to nonnormal distributions. Relationships between mean annual river flow and mean total parasite abundance 
Table 1. Site, code, mean annual river flow in 2003, sample size (N), mean standard length (SL), mean mass (M $\mathrm{M}_{\mathrm{W}}$ ) and mean Fulton's K condition factor (K) for 0-group sole Solea solea from 9 nurseries sampled along the French Atlantic coast. See Fig. 1 for locations on coasts of the English Channel or Bay of Biscay

\begin{tabular}{|lcccrrr|}
\hline Site & Code & $\begin{array}{c}\text { River flow } \\
\left(\mathrm{m}^{3} \mathrm{~s}^{-1}\right)\end{array}$ & $\mathrm{N}$ & $\begin{array}{c}\mathrm{SL} \pm \mathrm{SD} \\
\text { (size range) }(\mathrm{mm})\end{array}$ & $\left.\mathrm{M}_{\mathrm{W} \pm \mathrm{SD}(\mathrm{g})} \mathrm{K} \pm \mathrm{SD}(\mathrm{g} \mathrm{cm})^{-3}\right)$ \\
\hline Seine estuary & 1 & 500 & 15 & $92.9 \pm 8.6(58-109)$ & $9.2 \pm 2.6$ & $1.14 \pm 0.18$ \\
Orne estuary & 2 & 18 & 15 & $90.7 \pm 10.6(58-105)$ & $9.1 \pm 3.3$ & $1.18 \pm 0.09$ \\
Bay of Mont-Saint-Michel & 3 & 15 & 24 & $76.3 \pm 12.9(58-107)$ & $5.9 \pm 3.7$ & $1.19 \pm 0.10$ \\
Vilaine estuary & 4 & 72 & 20 & $105.6 \pm 12.0(77-120)$ & $13.2 \pm 4.4$ & $1.08 \pm 0.09$ \\
Loire estuary & 5 & 855 & 20 & $107.5 \pm 11.8(88-132)$ & $14.5 \pm 5.4$ & $1.11 \pm 0.08$ \\
Bay of Bourgneuf & 6 & 5 & 21 & $109.1 \pm 10.5(90-129)$ & $14.7 \pm 4.7$ & $1.10 \pm 0.10$ \\
Pertuis Breton & 7 & 10 & 10 & $105.4 \pm 9.0(91-118)$ & $13.6 \pm 3.7$ & $1.15 \pm 0.12$ \\
Pertuis d'Antioche & 8 & 58 & 20 & $94.7 \pm 6.6(81-118)$ & $9.3 \pm 2.2$ & $1.08 \pm 0.08$ \\
Gironde estuary & 9 & 1000 & 29 & $89.1 \pm 8.5(76-112)$ & $8.1 \pm 2.6$ & $1.11 \pm 0.06$ \\
\hline
\end{tabular}

(for each parasite taxon and total) were analysed with the non-parametric Spearman rank order correlation (SC). Relationships between parasite abundance (each parasite taxon and total) and SL and $\mathrm{K}$, respectively, were analysed with SC.

\section{RESULTS}

Standard length (SL), wet mass $\left(\mathrm{M}_{\mathrm{W}}\right)$ and Fulton's condition factor $(\mathrm{K})$ were significantly different among the 9 sites $\left(\mathrm{KW}_{\mathrm{SL}}, \chi^{2}=91.82, \mathrm{p}<0.001 ; \mathrm{KW}_{\mathrm{Mw}}, \chi^{2}=\right.$ 75.38, $\mathrm{p}<0.001 ; \mathrm{KW}_{\mathrm{K}}, \chi^{2}=23.74, \mathrm{p}=0.003 ; \mathrm{N}=174$ and $\mathrm{df}=8$ for each test). Random sub-sampling could not be verified and thus differences in SL, $\mathrm{M}_{\mathrm{W}}$ and $\mathrm{K}$ may not be taken as a direct reflection of the population parameters. However, the size range of fish overlapped substantially among samples from the 9 sites (Table 1), allowing us to compare parasite assemblages.

We identified 5 taxa of digenean metacercariae: Timoniella spp. (2 species) (Acanthostomidae), Prosorhynchus crucibulum and Prosorhynchus sp. A (Bucephalidae), Podocotyle sp. (Opecoelidae), and an unidentified taxon designated as Digenea sp. (Fig. 2). Metacercariae were encysted in body parts of all 0group sole, especially in muscle tissue or just underneath the skin, but were not present in organs.

Timoniella spp. metacercariae are filiform and characterized by an oral sucker surrounded by large spines (Maillard 1973, 1974) (Fig. 2A,B). T. imbuti-

Fig. 2. Photomicrographs of digenean metacercariae found in 0-group sole juveniles: (A) Timoniella spp.; (B) detail of the oral sucker surrounded with spines in Timoniella spp.; (C) Prosorhynchus crucibulum; (D) Prosorhynchus sp. A; (E) Podocotyle sp.; (F) Digenea sp. (unidentified metacercariae). Scale bars $=(\mathrm{A}, \mathrm{D}) 200 \mu \mathrm{m},(\mathrm{B}) 50 \mu \mathrm{m}$, (C) $500 \mu \mathrm{m}$, and (E,F) $100 \mu \mathrm{m}$

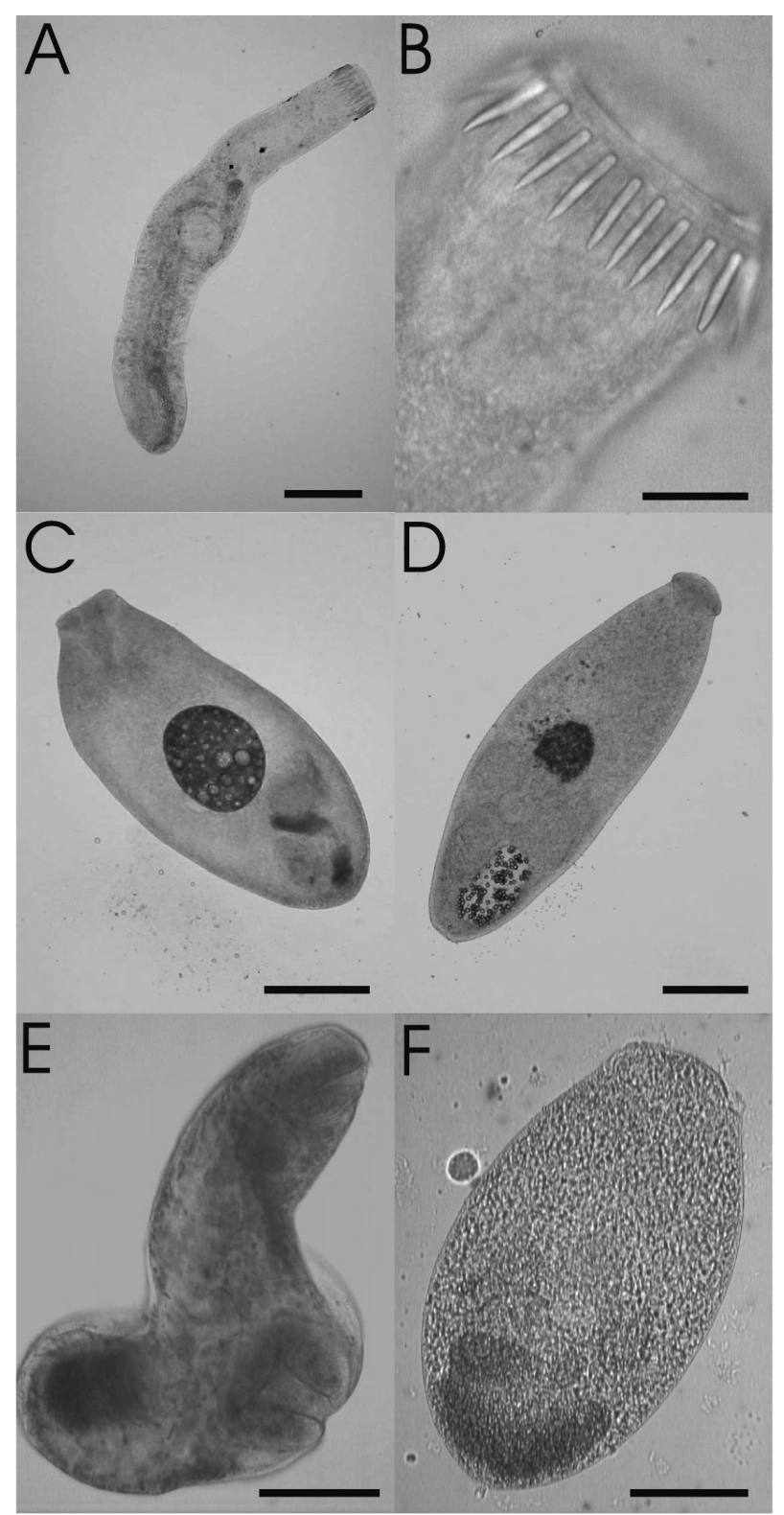


forme and T. praeterita are present in our study area and were distinguished by the number of oral spines (18 and 22, respectively) on a few specimens (Maillard 1973, 1974). However, due to their high abundance and the small size of these metacercariae, they were identified at only the genus level following ElDarsh \& Whitfield (1999) and Durieux et al. (2007). Prosorhynchus crucibulum metacercariae are large (around $2 \mathrm{~mm}$ ) and characterized by a wide V-shaped rhynchus, with the mouth located in a midventral position (Matthews 1973) (Fig. 2C). Prosorhynchus sp. A is smaller (around $1 \mathrm{~mm}$ ), characterized by a small, round rhynchus, with the mouth located midventrally in the posterior half of the body (Fig. 2D), morphological features typical of Prosorhynchus aculeatus (Jones 1943, Matthews 1973, Santos \& Gibson 2002). However, based on current molecular data (E. D. H. Durieux unpubl. data), we prefer to restrict the identification to Prosorhynchus sp. A. Podocotyle sp. metacercariae are characterized by a well developed ventral sucker (Koie 1981) (Fig. 2E). Digenea sp. metacercariae possessed no morphological features that enabled us to identify them to the genus or species level (Fig. 2F); the specimens were all similar and are believed to belong to a single species.

Voucher specimens for Prosorhynchus crucibulum, Prosorhynchus sp. A, Timoniella spp. and Podocotyle sp. have been deposited at the Museum National d'Histoire Naturelle (Paris, France) under accession numbers $531 \mathrm{HG}, 532 \mathrm{HG}, 533 \mathrm{HG}$ and $534 \mathrm{HG}$, respectively. Due to storage problems, this was not possible for Digenea sp.

Significant differences in parasite abundances were detected among the 9 sites for each taxon separately and for total abundance (Table 2$)\left(\mathrm{KW}_{\text {Timoniella spp. },} \chi^{2}=\right.$ 27.09, $\mathrm{p}=0.001 ; \mathrm{KW}_{\text {Prosorhynchus crucibulum, }} \chi^{2}=18.97, \mathrm{p}=$

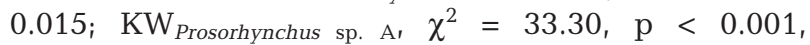
$\mathrm{KW}_{\text {Podocotyle sp. },} \chi^{2}=16.86, \mathrm{p}=0.032 ; \mathrm{KW}_{\text {Digenea sp. },} \chi^{2}=$ 95.63, $\mathrm{p}<0.001 ; \mathrm{KW}_{\text {total },} \chi^{2}=44.77, \mathrm{p}<0.001$, with $\mathrm{N}=$ 174 and $\mathrm{df}=8$ for all tests). Timoniella spp. infection was highest for Sites 4, 5, 6, 7 and 8, in terms of both prevalence and mean abundance. Prosorhynchus crucibulum infection was also high for Sites 4, 5, 6, 7 and 8, but with much lower values than for Timoniella spp. (Table 2). Prosorhynchus sp. A was found in only Sites 5, 7 and 8. Podocotyle sp. infection was high for Sites 3, 6, 7 and 8 . The unidentified metacercariae was present only in Sites 1 and 2.

We found a significant negative relationship between mean annual river flow and Timoniella spp. mean abundance ( $\mathrm{SC}, \mathrm{N}=6, \mathrm{R}=-0.886, \mathrm{p}=0.019$ ). An even more significant negative relationship between mean annual river flow and mean total parasite abundance was detected for Bay of Biscay sites ( $\mathrm{SC}, \mathrm{N}=6$, $\mathrm{R}=-0.943, \mathrm{p}=0.005$ ) but not for English Channel sites,

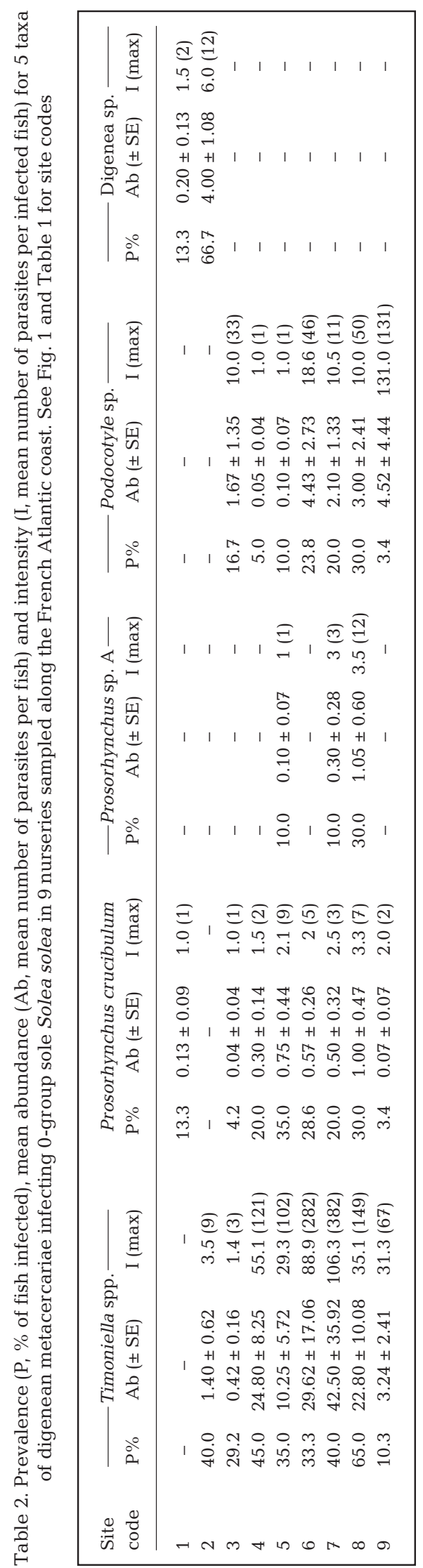


partly due to the low sample size $(\mathrm{SC}, \mathrm{N}=3, \mathrm{R}=$ -0.500, p > 0.05) (Fig. 3).

We found significant positive correlations between Timoniella spp. abundance and SL (SC, N = 20, R = $0.63, \mathrm{p}=0.003$ ) only at Site 5 , and between SL and total parasite abundance in Sites 5, 6 and $7\left(\mathrm{SC}_{5}, \mathrm{~N}=20, \mathrm{R}=\right.$ $0.660, \mathrm{p}=0.002 ; \mathrm{SC}_{6}, \mathrm{~N}=21, \mathrm{R}=0.536, \mathrm{p}=0.012 ; \mathrm{SC}_{7}$, $\mathrm{N}=10, \mathrm{R}=0.648, \mathrm{p}=0.043$ ). No significant negative relationship was detected between parasite abundance and condition factor $\mathrm{K}$ at any site ( $\mathrm{SC}, \mathrm{p}>0.05)$.

\section{DISCUSSION}

In our study area, 0-group sole colonize bays and estuaries in spring (Amara et al. 2000). They remain in soft bottom shallow water areas until the onset of winter, when they leave for deeper waters (Dorel et al. 1991). Our sampling was similar among 9 sites studied, i.e. in relatively deep parts of the nurseries (between 5 and $20 \mathrm{~m}$ depth), and in September and October, when infection had stabilized (Durieux et al. 2007). Thus, at this time of the year and at this depth of sampling, the high intra-site variability among fish may have been due to an earlier dispersal of 0-group sole individuals that had spent spring and summer accumulating metacercariae in different parts of the nursery grounds. Although our generally small sample size per nursery area, combined with the aggregated parasite distributions may have hidden the spatial variability at the observed scale, clear trends in the infection of 0-group sole by digenean metacercariae could still be distinguished. Therefore, the sampling within sites is thought to reflect the diversity of the parasite community of each nursery, allowing comparisons of parasitic infection on a wide spatial scale among nurseries and stock units.

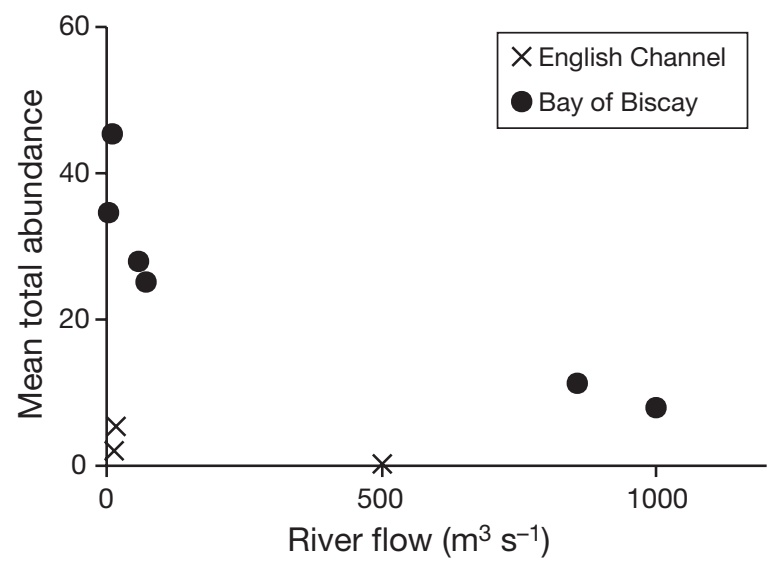

Fig. 3. Relationship between mean total abundance of digenean metacercariae in 0-group sole Solea solea and mean annual river flow in nursery grounds of the English Channel $(\mathrm{N}=3)$ and the Bay of Biscay $(\mathrm{N}=6)$ 0-group sole were infected by 3 identified genera of digenean metacercariae, Timoniella spp. (Acanthostomidae), Prosorhynchus crucibulum and Prosorhynchus sp. A (Bucephalidae), Podocotyle sp. (Opecoelidae) and by one unidentified species of Digenea. Timoniella spp. in the geographic area studied include $T$. imbutiforme and $T$. praeterita, species with exactly the same life cycle. The laver spire shell, Hydrobia spp. is first intermediate host. Second intermediate hosts are various small-sized fishes, both benthic and pelagic, whereas the definitive host is the European sea bass Dicentrarchus labrax (Maillard 1973, 1974). The first intermediate host of Prosorhynchus crucibulum is the blue mussel Mytilus edulis, the second intermediate hosts are various small benthic fishes, and the definitive host is the conger eel Conger conger (Matthews 1973). The first intermediate host of Prosorhynchus aculeatus (morphologically similar to Prosorhynchus sp. A in this study) remains unknown to our knowledge, and the definitive host is Conger conger. Although we could not identify Podocotyle sp. metacercariae to the species level, they were likely Podocotyle atomon, because this species dominates in fishes living in the littoral zone (like 0-group sole), whereas Podocotyle reflexa mostly occurs in fishes living in deeper coastal waters (Koie 1981). The first intermediate host of Podocotyle atomon is the periwinkle Littorina spp. ( $L$. littorea and L. saxatilis), the second intermediate host may be various fishes, but also crustaceans, and the definitive host role belongs to various marine piscivorous fishes (Koie 1981). The present study confirms 0-group common sole Solea solea as one of the second intermediate hosts of Timoniella spp. and Prosorhynchus crucibulum, and constitutes, to our knowledge, the first report for Podocotyle sp.

Comparing infection of 0-group sole at large spatial scales among nurseries, we generally found different parasite communities, and infection levels (prevalence and mean abundance) in the nurseries from the English Channel lower than those from the Bay of Biscay. Various large scale factors affecting both hosts and parasites may explain these latitudinal discrepancies (Rohde 2005). Since sole populations in the northeastern Atlantic region are genetically homogeneous (Exadactylos et al. 2003, Rolland et al. 2007), the hypothesis of differential host genetic resistance (Combes 2001) among regions can be rejected. Mean surface seawater temperature is generally lower in the English Channel than in the Bay of Biscay (Maillard 1986). As increased water temperature leads to increased cercarial production (Marcogliese 2001, Poulin 2006), this large scale factor may contribute to a lower accumulation of metacercariae in 0-group sole of the English Channel nurseries. 
Marine coastal mollusc (i.e. first intermediate hosts) communities have particularly high spatial heterogeneity at small scales (Blanchard \& Bourget 1999). Poulin \& Mouritsen (2003) demonstrated that smallscale local factors generally override effects of largerscale factors, making the detection of large-scale patterns in species richness or prevalence of digenean infections in molluscs difficult. In fact, first intermediate known hosts of the identified marine digeneans infecting 0-group sole are common inhabitants of intertidal areas, and the local distributions of different molluscs species are restricted within nursery grounds. Large populations of Hydrobia ulvae inhabit the large mudflats located at the bottoms of bays and at the mouths of estuaries (Sauriau et al. 1989, Sola 1996, Haubois et al. 2004). Large populations of mussel are cultivated on poles in legally regulated zones within soft bottom shallow areas of different small estuaries, and especially in bays such as Mont Saint Michel Bay, Bay of Bourgneuf, the Pertuis Breton and Pertuis d'Antioche in our study area (Goulletquer \& Le Moine 2002). Small Littorina spp. populations occur very patchily on rocky shores or on man-made hard substrata that are also found in soft bottom dominated shallow areas (Sauriau et al. 1989). In nursery grounds, due to the spatial heterogeneity of the first intermediate hosts, 0-group sole may be differentially exposed to digeneans, depending on their distribution and movements within the nursery.

The most significant difference in parasite load between the 2 stock areas was for Timoniella spp., which was absent in the Seine estuary and much less abundant in the Orne estuary and Mont Saint Michel Bay than in all nurseries of the Bay of Biscay, especially the embayments. Bocher et al. (2007) compared spatial patterns of different mudflat molluscs in northwestern Europe in the year of our study, and they reported a scarcity of Hydrobia ulvae in Mont Saint Michel Bay (2.5 ind $\mathrm{m}^{-2}$ ) compared to the very high densities reached in Aiguillon Bay and Marennes Oleron Bay (from 1664 to 3324 ind. $\mathrm{m}^{-2}$ ), mudflats located in the Pertuis Breton and the Pertuis d'Antioche, respectively. Thus, variation in Hydrobia ulvae abundance may make a considerable contribution to variation in abundance of metacercariae of Timoniella spp. in 0group sole juveniles, in accordance with the withinsite positive relationship (for different model organisms) between the abundance of first intermediate hosts and abundance of macroparasites in second intermediate aquatic hosts (Marcogliese et al. 2001, Latham \& Poulin 2003, Thieltges \& Karsten 2007).

Infection levels of Timoniella spp. and especially Prosorhynchus crucibulum were much lower for all sites than previously reported for the Pertuis Breton in a site under direct influence of the first intermediate hosts (Durieux et al. 2007). The cercariae of Timoniella spp. have flagellum-like tails, enabling them to swim and thus remain in the water column (Maillard 1973, 1974), and hence infest hosts distant from the cercariae shedding area, especially when strong currents occur (Durieux et al. 2007). Like all other Bucephalids, Prosorhynchus crucibulum cercariae have tails with 2 long furcae, so that they lie on the bottom (Matthews 1973) and have limited dispersal capacities (E. D. H. Durieux unpubl. data). Podocotyle sp. cercariae have short tails, and crawl on the substratum with the aid of 2 suckers (Koie 1981). Thus, the proximity of the first intermediate hosts and dispersal capacities of the cercariae may be another major local factor determining metacercariae load in 0-group sole.

In the Bay of Biscay nurseries, we found a strong significant relationship between mean river flow and mean total parasite abundance. River flow intensity is one of the main factors driving colonisation of nurseries by 0-group sole (Amara et al. 2000, Le Pape et al. 2003b). In estuaries, 0-group sole tend to concentrate and settle upstream in brackish waters (Coggan \& Dando 1988, Dorel et al. 1991, Cabral 2000), whereas in embayments with low freshwater input, the fish cannot undertake such migrations and remain in marine waters (Rogers 1992, Le Pape et al. 2003a). In other words, with increasing river flow, 0-group sole nurseries are located more upstream and in less saline waters. In parallel, first intermediate host populations of the marine digeneans are located in bays or at the mouths of estuaries, and their abundance decreases steadily upstream with decreasing salinity. In addition, production and/or infectivity of these marine parasite cercariae may decrease with decreasing salinity, as is known for other marine digeneans (Pietrock \& Marcogliese 2003). Therefore, within nurseries the control exerted by river flow on settlement zones of 0 group sole may also control the distance between fish and the most infective zone, and thus fish parasite load, as has already been suggested for 0-group juvenile European flounder Platichthys flesus in the Thames estuary (El-Darsh \& Whitfield 1999).

In conclusion, this study highlights spatial variability in the infection of 0 -group sole by digenean metacercariae among nurseries at different scales. Between the English Channel and the Bay of Biscay, differences in parasite abundance and community composition are thought to relate to variations in local distribution patterns of molluscan first intermediate hosts, and, to a lesser extent, to seawater temperature differences. At the scale of a single stock and comparing between nurseries, the most relevant factor influencing parasitism of 0-group sole appeared to be river flow, which acts by controlling the distance between fish and the area of greatest infection potential. Digenean meta- 
cercariae load in 0-group sole may be influenced by 3 major local factors, i.e. abundance and proximity of the first intermediate hosts and cercariae dispersal capacities. In studies of parasitism in sole juveniles living in embayed nurseries, special attention should be paid (at small spatial scales) to both natural and cultivated first intermediate host populations. Spatio-temporal variability of infection within nurseries and the impact of parasitism on sole performance (growth, immunity and behaviour) are the foci of present work seeking to accurately define the influence of parasitism on habitat quality. Studies on the relative contribution of different environmental factors (e.g. temperature, salinity, oxygen, water current and pollutants) to infection levels in sole nurseries remain to be conducted in the future.

Acknowledgements. A PhD grant to E.D.H.D. was funded by IFREMER and the Conseil Régional Poitou Charentes. We thank Y. Désaunay and O. Le Pape for providing sole samples from IFREMER surveys of the different nurseries. We are grateful to Y. Descatoires for drawing Fig. 1. We thank C. Arnaud for help in parasite collection. We thank M. Blouin from Oregon State University, the 3 anonymous reviewers and D. Marcogliese for valuable comments on an earlier version of the manuscript.

\section{LITERATURE CITED}

Able KW, Manderson JP, Studholme AL (1999) Habitat quality for shallow water fishes in an urban estuary: the effects of man-made structures on growth. Mar Ecol Prog Ser 187: $227-235$

Amara R, Lagardère F, Désaunay Y, Marchand J (2000) Metamorphosis and estuarine colonisation in the common sole, Solea solea (L.): implications for recruitment regulation. Oceanol Acta 23:469-484

Beck MW, Heck KL, Able KW, Childers DL and 9 others (2001) The identification, conservation, and management of estuarine and marine nurseries for fish and invertebrates. BioScience 51:633-641

Blanchard D, Bourget E (1999) Scales of coastal heterogeneity: influence on intertidal community structure. Mar Ecol Prog Ser 179:163-173

Bocher P, Piersma T, Dekinga A, Kraan C, Yates MG, Guyot T, Folmer EO, Radenac G (2007) Site- and species-specific distribution patterns of molluscs at five intertidal soft-sediment areas in northwest Europe during a single winter. Mar Biol 151:577-594

Bush AO, Lafferty KD, Lotz JM, Shostak AW (1997) Parasitology meets ecology on its own terms: Margolis et al. revisited. J Parasitol 83:575-583

Cabral HN (2000) Distribution and abundance patterns of flatfishes in the Sado Estuary, Portugal. Estuaries 23: 351-358

Coggan RA, Dando PR (1988) Movements of juvenile Dover sole, Solea solea (L.), in the Tamar estuary, south western England. J Fish Biol 33:177-184

Combes C (2001) Parasitism. The ecology and evolution of intimate interactions. Chicago University Press, Chicago, IL

Dorel D, Koutsikopoulos C, Désaunay Y, Marchand J (1991) Seasonal distribution of young sole (Solea solea (L.)) in the nursery ground of the Bay of Vilaine (Northern Bay of Biscay). Neth J Sea Res 27:297-306

Durieux EDH, Galois R, Bégout ML, Sasal P, Lagardère F (2007) Temporal changes in lipid condition and parasitic infection by digenean metacercariae of young-of-year common sole Solea solea (L.) in an Atlantic nursery ground (Bay of Biscay, France). J Sea Res 57:162-170

El-Darsh HEM, Whitfield PJ (1999) Digenean metacercariae (Timoniella spp., Labratrema minimus and Cryptocotyle concava) from flounder, Platichthys flesus, in the tidal Thames. J Helminth 73:103-113

Exadactylos A, Geffen AJ, Panagiotaki P, Thorpe JP (2003) Population structure of Dover sole Solea solea: RAPD and allozyme data divergence in European stocks. Mar Ecol Prog Ser 246:253-264

Gibson RN (1994) Impact of habitat quality and quantity on the recruitment of juvenile flatfishes. Neth J Sea Res 32: 191-206

Goulletquer P, Le Moine O (2002) Shellfish farming and coastal zone management (CZM) development in the Marennes-Oléron Bay and Charentais Sounds (Charente Maritime, France): a review of recent development. Aquaculture Int 10:507-525

Haubois AG, Guarini JM, Richard P, Hemon A, Arotcharen E, Blanchard GF (2004) Differences in spatial structures between juveniles and adults of the gastropod Hydrobia ulvae on an intertidal mudflat (Marennes-Oleron Bay, France) potentially affect estimates of local demographic processes. J Sea Res 51:63-68

ICES (International Council for Exploration of the Sea) (2005) Report of the ICES Advisory Committee on Fishery Management, Advisory Committee on the Marine Environment and Advisory Committee on Ecosystems, 2005. ICES Advice, Vol 1-11.1. ICES, Copenhagen

Jones DO (1943) The anatomy of three digenetic trematodes, Skrjabiniella aculeatus (Odhner), Lecithochirium rufoviride (Rud.) and Sterrhus fusiformis (Lühe) from Conger conger (Linn.). Parasitology 35:40-57

Koie M (1981) On the morphology and life-history of Podocotyle reflexa (Creplin, 1825) Odhner, 1905, and a comparison of its developmental stages with those of $P$. atomon (Rudolphi, 1802) Odhner, 1905 (Trematoda, Opecoelidae). Ophelia 20:17-43

Laffargue P, Baudoin G, Sasal P, Arnaud C, Bégout Anras ML, Lagardère F (2004) Parasitic infection of sole Solea solea by Prosorhynchus spp. metacercariae (Digenea, Bucephalidae) in Atlantic nurseries under mussel cultivation influence. Dis Aquat Org 58:179-184

Lafferty KD, Dobson AP, Kuris A (2006) Parasites dominate food web links. Proc Natl Acad Sci USA 103:11211-11216

Latham A, Poulin R (2003) Spatiotemporal heterogeneity in recruitment of larval parasites to shore crab intermediate hosts: the influence of shorebird definitive hosts. Can J Zool 81:1282-1291

Le Pape O, Chauvet F, Mahevas S, Lazure P, Guérault D, Désaunay Y (2003a) Quantitative description of habitat suitability for the juvenile common sole (Solea solea, L.) in the Bay of Biscay (France) and the contribution of different habitats to the adult population. J Sea Res 50:139-149

Le Pape O, Holley J, Guérault D, Désaunay Y (2003b) Quality of coastal and estuarine essential fish habitats: estimations based on the size of juvenile common sole (Solea solea L.). Est Coast Shelf Sci 58:793-803

Maillard C (1973) Etude du cycle évolutif du Trématode Acanthostomum imbutiforme (Molin, 1859) Gohar, 1934, parasite of Morone labrax (Linne, 1758). Ann Parasit Humaine Comp 48:33-46 
Maillard C (1974) Cycle évolutif de Timoniella praeteritum (Loss 1901) (Trematoda, Acanthostomidae) parasite de Morone labrax (teleostei, Serranidae). Bull Soc Zool Fr 99:245-257

Maillard C (1986) Atlas hydrologique de l'Atlantique NordEst. IFREMER, Brest

Marcogliese DJ (2001) Implications of climate change for parasitism of animals in the aquatic environment. Can J Zool 79:1331-1352

Marcogliese DJ, Compagna S, Bergeron E, McLaughlin JD (2001) Population biology of eyeflukes in fish from a large fluvial ecosystem: the importance of gulls and habitat characteristics. Can J Zool 79:1102-1113

Matthews RA (1973) The life-cycle of Prosorhynchus crucibulum (Rudolphi, 1819 Odhner, 1905, and a comparison of its cercaria with that of Prosorhynchus squamatus Odhner, 1905. Parasitology 66:133-164

Pietrock M, Marcogliese DJ (2003) Free-living endohelminth stages: at the mercy of environmental conditions. Trends Parasitol 19:293-299

Poulin R (2006) Global warming and temperature-mediated increases in cercarial emergence in trematode parasites. Parasitology 132:143-151

Poulin R, Mouritsen KN (2003) Large-scale determinants of trematode infections in intertidal gastropods. Mar Ecol Prog Ser 254:187-198

Rijnsdorp AD, Van Beek FA, Flatman S, Millner RM, Riley JD, Giret M, de Clerck R (1992) Recruitment of sole stocks, Solea solea (L.), in the Northeast Atlantic. Neth J Sea Res 29:173-192

Rogers SI (1992) Environmental factors affecting the distribution of sole (Solea solea (L.)) within a nursery area. Neth J Sea Res 29:153-161

Editorial responsibility: David Marcogliese, Montreal, Quebec, Canada
Rohde K (2005) Latitudinal, longitudinal and depth gradients. In: Rohde K (ed) Marine parasitology. CSIRO Publishing, Melbourne, p 348-351

Rolland JL, Bonhomme F, Lagardère F, Hassan M, Guinand B (2007) Population structure of the common sole (Solea solea) in the Northeastern Atlantic and the Mediterranean Sea: revisiting the divide with EPIC markers. Mar Biol 151:327-341

Santos MJ, Gibson DI (2002) Morphological features of Prosorhynchus crucibulum and P. aculeatus (Digenea: Bucephalidea), intestinal parasites of Conger conger (Pisces: Congridae), elucidated by scanning electron microscopy. Folia Parasitol 49:96-102

Sauriau PG, Mouret V, Rincé JP (1989) Organisation trophique de la malacofaune benthique non cultivée du bassin ostréicole de Marennes-Oléron. Oceanol Acta 12: 193-204

Sola JC (1996) Population dynamics, reproduction, growth, and secondary production of the mud-snails Hydrobia ulvae (Pennant). J Exp Mar Biol Ecol 205: 49-62

Thieltges DW, Karsten R (2007) Spatial heterogeneity in parasite infections at different spatial scales in an intertidal bivalve. Oecologia 150:569-581

Thomas F, Cezilly F, de Meeus T, Crivelli AJ, Renaud F (1997) Parasitism and ecology of wetlands: a review. Estuaries 20: 646-654

Thomas F, Renaud F, Guégan JF (eds) (2005) Parasitism and ecosystems. Oxford University Press, New York

Yamashita Y, Tanaka M, Miller JM (2001) Ecophysiology of juvenile flatfish in nursery grounds. J Sea Res 45: 205-218

Submitted: November 8, 2006; Accepted: February 21, 2007 Proofs received from author(s): April 19, 2007 